\title{
(C) OPEN ACCESS \\ Do difficulties in accessing in-hours primary care predict higher use of out-of-hours GP services? Evidence from an English National Patient Survey
}

\author{
Yin Zhou, ${ }^{1}$ Gary Abel, ${ }^{1}$ Fiona Warren, ${ }^{2}$ Martin Roland, ${ }^{1}$ John Campbell, ${ }^{2}$ \\ Georgios Lyratzopoulos ${ }^{1}$
}

- Additional material is published online. To view please visit the journal (http:// dx.doi.org/10.1136/emermed2013-203451)

${ }^{1}$ Cambridge Centre for Health Services Research, Institute of Public Health, University of Cambridge, Cambridge, Cambridgeshire, UK

${ }^{2}$ Primary Care Research Group Peninsula Medical School, Plymouth, Exeter, UK

\section{Correspondence to} Dr Yin Zhou, Cambridge Centre for Health Services Research, Institute of Public Health, Forvie Site, Cambridge, Cambridgeshire CB2 OSR, UK; ykz21@medschl.cam.ac.uk

Received 3 December 2013 Revised 29 January 2014 Accepted 19 February 2014

Published Online First

21 May 2014

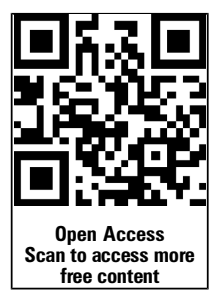

CrossMark

To cite: Zhou Y, Abel G Warren $F$, et al. Emerg Med J 2015;32:373-378.

\section{ABSTRACT}

Introduction It is believed that some patients are more likely to use out-of-hours primary care services because of difficulties in accessing in-hours care, but substantial evidence about any such association is missing.

Methods We analysed data from 567049 respondents to the 2011/2012 English General Practice Patient Survey who reported at least one in-hours primary care consultation in the preceding 6 months. Of those respondents, $7 \%$ also reported using out-of-hours primary care. We used logistic regression to explore associations between use of out-of-hours primary care and five measures of in-hours access (ease of getting through on the telephone, ability to see a preferred general practitioner, ability to get an urgent or routine appointment and convenience of opening hours). We illustrated the potential for reduction in use of out-ofhours primary care in a model where access to in-hours care was made optimal.

Results Worse in-hours access was associated with greater use of out-of-hours primary care for each access factor. In multivariable analysis adjusting for access and patient characteristic variables, worse access was independently associated with increased out-of-hours use for all measures except ease of telephone access. Assuming these associations were causal, we estimated that an $11 \%$ relative reduction in use of out-of-hours primary care services in England could be achievable if access to in-hours care were optimal.

Conclusions This secondary quantitative analysis provides evidence for an association between difficulty in accessing in-hours care and use of out-of-hours primary care services. The findings can motivate the development of interventions to improve in-hour access.

\section{INTRODUCTION}

Use of out-of-hours primary care services is perceived to be expensive ${ }^{1} 2$ and presents patient safety challenges. ${ }^{3}$ In addition, by definition, out-of-hours use disrupts relational continuity of care, posing problems for many doctors who may be unfamiliar with complex patients with multiple morbidities, and patients who may prefer to see their regular doctor. ${ }^{4-6}$

For the above reasons, reducing demand for out-of-hours primary care is seen as a reasonable goal for modern healthcare systems. How to achieve such a reduction in out-of-hours primary care is nevertheless not well understood. A popular hypothesis put forward by many managers and politicians ${ }^{7}$ is that difficulties in accessing daytime

\section{Key messages}

What is already known on this subject

- Provision of out-of-hours primary care presents many challenges for modern healthcare systems.

- Previous studies have suggested that poorer in-hours access to a general practitioner (GP) is associated with increased use of out-of-hours primary care but were limited in sample size and the number of access measures they have examined.

What this study adds

- In a large national survey of patients, self-reported difficulty in accessing a GP within standard opening hours was associated with increased use of out-of-hours primary care services, independently of age, gender, ethnicity, deprivation, chronic disease and employment status.

- The relationship between convenience of opening hours, our strongest predictor, and out-of-hours primary care use was strongest among patients not in employment or education, indicating that a potential way to reducing demand for out-ofhours primary care is by improving in-hours access (rather than extending opening hours).

- If the described association was causal, a maximum $11 \%$ reduction in demand for out-ofhours primary care may be achievable.

primary care services may be fuelling the increased use of out-of-hours services, including emergency and out-of hours primary care.

Against this background we analysed recent data from the English General Practice Patient Survey to explore the associations between patient-reported measures of ease of accessing in-hours primary care and the use of out-of-hours primary care services. We conducted this study with a view to identifying potential improvements in accessing primary care services that could lead to a reduction in use of out-of-hours primary care.

\section{METHODS}

Data

Data from the 2011/2012 English General Practice Patient Survey (GPPS) were used for the analysis. 
Box 1 Outcome question as it appears in the 2011/2012

GPPS. Note: Only patients who replied 'yes, for myself' or

'no...' were included in subsequent analysis

Q37: In the past 6 months, have you tried to call an out-of-hours general practitioner service when the surgery was closed?

$\square$ Yes, for myself

$\square$ Yes, for someone else

$\square$ No. Go to Q42

The GPPS is a national patient experience questionnaire sent to about 2.7 million patients registered with a GP practice. The survey has a random stratified (by age, sex and practice) sample covering all 8271 practices in England. The overall response rate was $38 \% .{ }^{8}$ Non-identifiable data were used in this research, and no ethical approval was required. A full description of the GP Patient Survey design and administration, including the necessary data governance arrangements, has been published previously. ${ }^{8}$

We restricted analysis to respondents who indicated that they saw or spoke to a GP in the last 6 months. A dichotomous outcome variable was created indicating whether or not patients also reported trying to call an out-of-hours GP service for themselves in the last 6 months (box 1). In the UK, the first point of contact with out-of-hours primary care service is through a telephone triage service, after which subsequent care is provided through various pathways (including telephone consultations, face-to-face consultations, home visits or referrals to secondary care).

We explored the association between in-hours general practice access and use of out-of-hours primary care services using five different patient-reported in-hours access measures included in the General Practice Patient Survey: (1) ease of getting through the practice on the telephone, (2) frequency of seeing or speaking to preferred GP (interpersonal continuity of care), (3) ability to book an appointment within 2 working days (urgent), (4) ability to get an appointment 2 days ahead or more (routine), and (5) convenience of opening hours (see GPPS questions Q3, Q8-9, Q10-12 and Q26, and also online supplementary appendix 1). Adjustment was made for gender, age, ethnicity, small area deprivation (using quintiles of the Index of Multiple Deprivation 2010 score of patient's residence ${ }^{9}$ ), presence of a chronic condition and employment status (see online supplementary appendix 2). Of these factors, deprivation is the only non-self-reported measure. The choice of adjustors was informed by evidence indicating that adjustments for gender, age, ethnicity and deprivation may affect reports of patient experience and that employment status (including the ability to take time off work) may be a key factor in determining experience of access. ${ }^{10} 11$ We also hypothesised a priori that chronic disease status may be an important factor in determining experience of access.

\section{Analysis}

First, we used logistic regression models to explore associations between individual exposure variables (ie, in-hours access measures) and out-of-hours primary care service use, without and with adjustment (results not shown) for patient sociodemographics. Second, we considered all access measures and all sociodemographic variables in one single model. Because patients could only answer either the item on ability to book 'urgent' (within 2 days) appointments or the item on ability to book 'routine' (after 2 days or later) appointments, these two items were combined into one variable: 'ability to get an appointment'. Furthermore, this model included a random effect for GP practice to control for clustering of poor access at the practice level.

Next, we explored potential interactions between the access variables and two patient-level covariables-employment status and chronic disease status. We did so because of prior considerations that employment status may impact on the likelihood of use of in-hours care, ${ }^{12}$ and also because a proportion of out-of-hours use might be preventable among chronic disease sufferers with better in-hours access. ${ }^{13}$ A stepwise approach was taken retaining only those interactions terms that were statistically significant.

Finally, assuming that the observed association was causal, we explored the potential maximum reduction in out-of-hours primary care use that could be achievable by optimising the experience of in-hours access measures for all patients. This reduction was estimated by setting all the access scores to the best categories. The relative reduction in use of out-of-hours primary care was subsequently calculated. All analyses were conducted using Stata v11.2.

\section{RESULTS}

Of 767317 patients who reported at least one in-hours contact with a GP in the last 6 months, a final sample size of 567049 patients was used for the analysis. We excluded patients who reported that they had used out-of-hours service for someone else or did not respond to this question, and patients with missing sociodemographic information. Seven per cent $(40$ 108) of patients in the analysis sample reported using out-of-hours GP services for themselves in the last 6 months.

\section{Crude associations between each measure of in-hours access and out-of-hours service use}

We found evidence $(p<0.001)$ that, for each of the five in-hours access measures, poor reported experience was associated with higher use of out-of-hours services (table 1). For example, difficulty in getting through to the surgery by telephone was associated with an increased likelihood of out-of-hours use (OR $1.54,95 \%$ CI 1.47 to 1.61 'not at all easy' vs 'very easy'). After adjusting each association between out-of-hours use and the individual in-hours access measures for sociodemographic variables, we found little difference between the crude and adjusted effects (results not shown). This suggests that there was no substantial confounding of the association between in-hours access and out-of-hours service use by age, gender, ethnicity, deprivation, chronic condition status and employment status.

\section{Adjusted multivariable model}

In the adjusted model (all measures of in-hours access, adjusted for sociodemographic variables and including a random effect for general practice), there remained evidence $(p<0.001)$ for independent associations between increased out-of-hours GP use and each of the four in-hours access measures (table 1). However, while in general poor reported in-hours experience was associated with an increased frequency of out-of-hours use, the observed crude association with reported telephone access was lost after adjusting for other exposures. The strongest adjusted association was seen between convenience of opening hours and use of out-of-hours services (OR 1.42, 98\% CI 1.36 to 1.50$)$. 
Table 1 Frequency distribution and ORs of out-of-hours use across all variables

\begin{tabular}{|c|c|c|c|c|c|c|c|c|}
\hline \multirow[b]{2}{*}{ Access factor } & \multirow[b]{2}{*}{ Response category } & \multirow{2}{*}{$\begin{array}{l}\text { Number } \\
\text { of patients }\end{array}$} & \multirow{2}{*}{$\begin{array}{l}\text { Number of patients } \\
\text { reporting } \\
\text { out-of-hours use }\end{array}$} & \multirow{2}{*}{$\begin{array}{l}\text { Percentage } \\
\text { reporting } \\
\text { out-of-hours } \\
\text { use }(\%)\end{array}$} & \multicolumn{2}{|l|}{ Unadjusted model* } & \multicolumn{2}{|l|}{$\begin{array}{l}\text { Adjusted modelt } \\
(n=214139)\end{array}$} \\
\hline & & & & & OR $(95 \% \mathrm{Cl})$ & p Value & OR $(95 \% \mathrm{CI})$ & p Value \\
\hline $\begin{array}{l}\text { Ability to get } \\
\text { through to surgery } \\
\text { on telephone } \\
(n=556133)\end{array}$ & $\begin{array}{l}\text { Very easy } \\
\text { Fairly easy } \\
\text { Not very easy } \\
\text { Not at all easy }\end{array}$ & $\begin{array}{r}230268 \\
246066 \\
59092 \\
20707\end{array}$ & $\begin{array}{r}15782 \\
16541 \\
5179 \\
2106\end{array}$ & $\begin{array}{r}6.85 \\
6.72 \\
8.76 \\
10.17\end{array}$ & $\begin{array}{l}\text { Ref } \\
0.98(0.96 \text { to } 1.00) \\
1.31(1.26 \text { to } 1.35) \\
1.54(1.47 \text { to } 1.61)\end{array}$ & $<0.001$ & $\begin{array}{l}\text { Ref } \\
0.82(0.79 \text { to } 0.85) \\
0.95(0.90 \text { to } 1.01) \\
0.99(0.92 \text { to } 1.07)\end{array}$ & $<0.001$ \\
\hline $\begin{array}{l}\text { Ability to see } \\
\text { preferred GP } \\
(n=341446)\end{array}$ & $\begin{array}{l}\text { Always/almost } \\
\text { always } \\
\text { A lot of the time } \\
\text { Some of the time } \\
\text { Never or almost } \\
\text { never }\end{array}$ & $\begin{array}{l}175196 \\
78546 \\
75813 \\
11891\end{array}$ & $\begin{array}{r}11395 \\
6574 \\
7151 \\
1188\end{array}$ & $\begin{array}{l}8.37 \\
9.43 \\
9.99\end{array}$ & $\begin{array}{l}1.31(1.27 \text { to } 1.36) \\
1.50(1.45 \text { to } 1.54) \\
1.60(1.50 \text { to } 1.70)\end{array}$ & $<0.001$ & $\begin{array}{l}1.24(1.19 \text { to } 1.29) \\
1.27(1.22 \text { to } 1.33) \\
1.26(1.16 \text { to } 1.38)\end{array}$ & $<0.001$ \\
\hline $\begin{array}{l}\text { Ability to get } \\
\text { urgent } \\
\text { appointment } \\
(n=235285)\end{array}$ & $\begin{array}{l}\text { Yes } \\
\text { No }\end{array}$ & $\begin{array}{r}177574 \\
57711\end{array}$ & $\begin{array}{r}13840 \\
5605\end{array}$ & $\begin{array}{l}7.79 \\
9.71\end{array}$ & $\begin{array}{l}\text { Ref } \\
1.27(1.23 \text { to } 1.31)\end{array}$ & $<0.001$ & - & - \\
\hline $\begin{array}{l}\text { Ability to get } \\
\text { routine } \\
\text { appointment } \\
(n=130828)\end{array}$ & $\begin{array}{l}\text { Yes } \\
\text { No }\end{array}$ & $\begin{array}{r}111870 \\
18958\end{array}$ & $\begin{array}{l}4992 \\
1335\end{array}$ & $\begin{array}{l}4.46 \\
7.04\end{array}$ & $\begin{array}{l}\text { Ref } \\
1.62(1.52 \text { to } 1.73)\end{array}$ & $<0.001$ & - & - \\
\hline $\begin{array}{l}\text { Ability to get an } \\
\text { appointment } \\
\text { (n=366 113) }\end{array}$ & $\begin{array}{l}\text { Yes } \\
\text { No }\end{array}$ & $\begin{array}{r}270612 \\
69729\end{array}$ & $\begin{array}{r}18832 \\
6940\end{array}$ & $\begin{array}{l}6.5 \\
9.1\end{array}$ & $\begin{array}{l}- \\
-\end{array}$ & - & $\begin{array}{l}\text { Ref } \\
1.21 \text { (1.17 to } 1.27)\end{array}$ & $<0.001$ \\
\hline $\begin{array}{l}\text { Convenience of } \\
\text { opening hours } \\
(n=538911)\end{array}$ & $\begin{array}{l}\text { Convenient } \\
\text { Not convenient }\end{array}$ & $\begin{array}{r}475551 \\
63360\end{array}$ & $\begin{array}{r}31377 \\
6228\end{array}$ & $\begin{array}{l}6.2 \\
8.77\end{array}$ & $\begin{array}{l}\text { Ref } \\
1.54 \text { (1.50 to } 1.59)\end{array}$ & $<0.001$ & $\begin{array}{l}\text { Ref } \\
1.42(1.36 \text { to } 1.50)\end{array}$ & $<0.001$ \\
\hline $\begin{array}{l}\text { Gender } \\
(n=567049)\end{array}$ & $\begin{array}{l}\text { Male } \\
\text { Female }\end{array}$ & $\begin{array}{r}241,007 \\
301267\end{array}$ & $\begin{array}{l}15333 \\
24775\end{array}$ & $\begin{array}{l}6.36 \\
7.60\end{array}$ & $\begin{array}{l}\text { Ref } \\
1.21(1.19 \text { to } 1.24)\end{array}$ & $<0.001$ & $\begin{array}{l}\text { Ref } \\
1.08(1.05 \text { to } 1.12)\end{array}$ & $<0.001$ \\
\hline Age $(n=567049)$ & $\begin{array}{l}18-24 \\
24-34 \\
25-44 \\
45-54 \\
55-64 \\
65-74 \\
75-84 \\
85 \text { or over }\end{array}$ & $\begin{array}{r}20325 \\
46945 \\
63950 \\
86742 \\
111103 \\
109787 \\
68218 \\
19871\end{array}$ & $\begin{array}{l}2270 \\
4746 \\
5574 \\
6083 \\
6505 \\
6328 \\
5821 \\
2781\end{array}$ & $\begin{array}{r}10.1 \\
9.2 \\
8.0 \\
6.6 \\
5.5 \\
5.5 \\
7.9 \\
12.3\end{array}$ & $\begin{array}{l}1.59 \text { ( } 1.51 \text { to } 1.68) \\
1.44 \text { ( } 1.39 \text { to } 1.50) \\
1.24(1.20 \text { to } 1.29) \\
0.83 \text { ( } 0.81 \text { to } 0.87) \\
\text { Ref } \\
0.82 \text { (0.79 to } 0.85) \\
1.22(1.17 \text { to } 1.26) \\
2.00 \text { (1.90 to } 2.09)\end{array}$ & $<0.001$ & $\begin{array}{l}2.69 \text { (2.45 to } 2.95) \\
2.56(2.40 \text { to } 2.74) \\
1.92(1.81 \text { to } 2.04) \\
1.38(1.30 \text { to } 1.46) \\
\text { Ref } \\
0.84 \text { (0.79 to } 0.89) \\
1.09 \text { (1.03 to } 1.16) \\
1.58 \text { (1.44 to } 1.72)\end{array}$ & $<0.001$ \\
\hline $\begin{array}{l}\text { Ethnicity } \\
(n=567049)\end{array}$ & $\begin{array}{l}\text { White } \\
\text { Mixed } \\
\text { Asian } \\
\text { Black } \\
\text { Other }\end{array}$ & $\begin{array}{r}466777 \\
3685 \\
30790 \\
14264 \\
11425\end{array}$ & $\begin{array}{r}34515 \\
370 \\
2813 \\
982 \\
1428\end{array}$ & $\begin{array}{r}6.9 \\
9.1 \\
8.4 \\
6.4 \\
11.1\end{array}$ & $\begin{array}{l}\text { Ref } \\
1.36(1.22 \text { to } 1.51) \\
1.24(1.19 \text { to } 1.29) \\
0.93(0.87 \text { to } 0.99) \\
1.69 \text { (1.60 to } 1.79)\end{array}$ & $<0.001$ & $\begin{array}{l}\text { Ref } \\
1.18 \text { (1.00 to } 1.41) \\
1.08 \text { (1.01 to } 1.15) \\
0.72(0.64 \text { to } 0.81) \\
1.39 \text { (1.26 to } 1.53)\end{array}$ & $<0.001$ \\
\hline $\begin{array}{l}\text { Deprivation } \\
(n=567049)\end{array}$ & $\begin{array}{l}\text { Quintile } 1 \text { (highest) } \\
\text { Quintile } 2 \\
\text { Quintile } 3 \\
\text { Quintile } 4 \\
\text { Quintile } 5\end{array}$ & $\begin{array}{l}101699 \\
108014 \\
108025 \\
103650 \\
105553\end{array}$ & $\begin{array}{l}6702 \\
7487 \\
7950 \\
8347 \\
9622\end{array}$ & $\begin{array}{l}6.2 \\
6.5 \\
6.9 \\
7.5 \\
8.4\end{array}$ & $\begin{array}{l}\text { Ref } \\
1.05 \text { (1.02 to } 1.09) \\
1.12(1.08 \text { to } 1.15) \\
1.22(1.18 \text { to } 1.26) \\
1.38 \text { (1.34 to } 1.43)\end{array}$ & $<0.001$ & $\begin{array}{l}\text { Ref } \\
1.07 \text { (1.02 to } 1.13) \\
1.05(0.99 \text { to } 1.11) \\
1.10(1.04 \text { to } 1.16) \\
1.23(1.17 \text { to } 1.30)\end{array}$ & $<0.001$ \\
\hline $\begin{array}{l}\text { Presence of } \\
\text { chronic disease } \\
(n=567049)\end{array}$ & $\begin{array}{l}\text { No } \\
\text { Yes }\end{array}$ & $\begin{array}{l}157175 \\
369766\end{array}$ & $\begin{array}{r}8885 \\
31223\end{array}$ & $\begin{array}{l}5.4 \\
7.8\end{array}$ & $\begin{array}{l}\text { Ref } \\
1.49 \text { (1.46 to } 1.53)\end{array}$ & $<0.001$ & $\begin{array}{l}\text { Ref } \\
1.74 \text { (1.66 to } 1.82)\end{array}$ & $<0.001$ \\
\hline Occupational & Full time-able to & 114696 & 6658 & 5.5 & Ref & & Ref & \\
\hline$(n=567049)$ & $\begin{array}{l}\text { Full time-unable to } \\
\text { take time off work }\end{array}$ & 44469 & 3320 & 7.0 & 1.29 (1.23 to 1.34$)$ & $<0.001$ & 1.06 (0.99 to 1.14$)$ & $<0.001$ \\
\hline & $\begin{array}{l}\text { Part time-able to } \\
\text { take time off work }\end{array}$ & 45827 & 3146 & 6.4 & 1.18 (1.13 to 1.24$)$ & & 1.30 (1.21 to 1.39$)$ & \\
\hline & $\begin{array}{l}\text { Part-time-unable } \\
\text { to take time off } \\
\text { work }\end{array}$ & 19301 & 1520 & 7.3 & 1.36 (1.28 to 1.44$)$ & & 1.14 (1.04 to 1.25$)$ & \\
\hline & Full time education & 7822 & 736 & 8.6 & 1.62 (1.50 to 1.76$)$ & & 1.09 (0.94 to 1.25$)$ & \\
\hline & $\begin{array}{l}\text { Not in work or } \\
\text { education } \ddagger\end{array}$ & 294826 & 24728 & 7.7 & 1.44 (1.41 to 1.49$)$ & & $1.52(1.45$ to 1.61$)$ & \\
\hline
\end{tabular}

*Estimated from unadjusted analysis between each individual exposure or sociodemographic variable and out-of-hours use; $p<0.001$ for all association (joint tests for categorical variables).

tEstimated from one multivariate model adjusted for all exposure variables, gender, age, ethnicity, deprivation (using Index of Multiple Deprivation 2010 cut-offs), presence of chronic conditions, occupational status and random effect for practice; $p<0.001$ for all associations (joint Wald tests for categorical variables).

¥Not in work or education includes unemployed, permanently sick or disabled, fully retired from work, looking after the home, doing something else.

GP, general practitioner. 
Table 2 Variation by employment status in the association between use of out-of-hours primary care services and ability to see preferred GP or convenience of opening hours (from interaction analysis - see 'Methods', the variation is only shown for those variables where statistically significant interactions were found)

\begin{tabular}{|c|c|c|c|c|c|c|}
\hline & \multicolumn{2}{|c|}{ Full-time employment } & \multicolumn{2}{|c|}{ Part-time employment } & \multirow[b]{2}{*}{$\begin{array}{l}\text { Full-time } \\
\text { education }\end{array}$} & \multirow[b]{2}{*}{$\begin{array}{l}\text { Not in work or } \\
\text { educationt }\end{array}$} \\
\hline & $\begin{array}{l}\text { Able to take } \\
\text { time off work }\end{array}$ & $\begin{array}{l}\text { Unable to take } \\
\text { time off work }\end{array}$ & $\begin{array}{l}\text { Able to take } \\
\text { time off work }\end{array}$ & $\begin{array}{l}\text { Unable to take } \\
\text { time off work }\end{array}$ & & \\
\hline \multicolumn{7}{|l|}{ Ability to see preferred GP* } \\
\hline Always & Ref & Ref & Ref & Ref & Ref & Ref \\
\hline A lot of the time & 1.23 (1.11 to 1.36$)$ & 1.30 (1.11 to 1.53$)$ & $1.22(1.06$ to 1.40$)$ & $0.90(0.72$ to 1.13$)$ & $0.97(0.70$ to 1.36$)$ & $1.26(1.20$ to 1.33$)$ \\
\hline $\begin{array}{l}\text { Some of the time } \\
\text { (old models) }\end{array}$ & 1.30 (1.18 to 1.44$)$ & 1.44 (1.24 to 1.67$)$ & 1.15 (1.00 to 1.33$)$ & $1.13(0.92$ to 1.40$)$ & $0.92(0.67$ to 1.26$)$ & 1.27 (1.20 to 1.35$)$ \\
\hline Never or almost never & 1.21 (1.01 to 1.46$)$ & 1.37 (1.11 to 1.70$)$ & $1.01(0.74$ to 1.38$)$ & 1.01 (0.72 to 1.42$)$ & $1.82(1.15$ to 2.89$)$ & $1.31(1.15$ to 1.49$)$ \\
\hline \multicolumn{7}{|c|}{ Convenience of opening hours** } \\
\hline Convenient & Ref & Ref & Ref & Ref & Ref & Ref \\
\hline Not convenient & 1.17 (1.07 to 1.29$)$ & 1.23 (1.09 to 1.38$)$ & 1.43 (1.21 to 1.69$)$ & 1.51 (1.25 to 1.81$)$ & 1.37 (1.03 to 1.83$)$ & $1.76(1.62$ to 1.90$)$ \\
\hline
\end{tabular}

Almost two-thirds of all respondents indicated a preference for interpersonal continuity of care. Compared to those reporting the best experience of continuity of care, patients reporting less favourable experiences were more likely to use out-of-hours services (eg, OR 1.26, 95\% CI 1.16 to 1.38 for patients who could see their preferred doctor 'never or almost never' vs 'always or almost always'). Patients who were unable to get an appointment when they wanted one were more likely to report using out-of-hours services (adjusted OR 1.21, 95\% CI 1.17 to 1.27 'yes' vs 'no').

\section{Interaction models}

There was evidence for an interaction between employment status and continuity of care, and also with convenience of opening hours $(p=0.03$ and $p<0.001$, respectively) but not with any other measure we examined (table 2). The relationship between continuity of care and out-of-hours use did not show a clear pattern of variation between patients from different employment groups. On the other hand, the association between convenience of opening hours and out-of-hours use tended to be stronger among patients who were in part-time employment and those not in work or education. There was no evidence of interactions between chronic disease status and the exposure variables $(p>0.1$ for all). This suggests that the relationship between access to in-hours primary care and use of out-of-hours GP services did not differ significantly between patients with and without chronic diseases.

\section{Predicted reduction in reported out-of-hours use}

Assuming that the observed association between in-hours access and out-of-hours primary care use is causal, we estimate that there would be an $11 \%$ relative reduction in the proportion of patients who use out-of-hours primary care if it were possible to achieve optimal experience of access to in-hours primary care for all patients (table 3 ). It should be noted that this reduction is estimated only for those patients who have seen their GP in the last 6 months.

\section{DISCUSSION}

Our findings indicate that difficulty in accessing in-hours services in English general practice is associated with increased use of out-of-hours primary care services, regardless of age, gender, ethnicity, deprivation, presence of chronic disease and employment status. On further exploration of the associations between different employment groups, we found that the relationship between convenience of opening hours, our strongest predictor, and out-of-hours use was the strongest among unemployed patients. To demonstrate the potential for reduction in use of out-of-hours primary care, we developed a model where in-hours access was made optimal assuming that the associations observed were causal. A maximum of $11 \%$ relative reduction was estimated to be achievable.

Previous studies on primary care access have explored associations between primary care access and emergency department attendance and hospital admissions. ${ }^{13-19}$ For example, a recent ecological study explored the association of in-hours access measures and attendance of emergency department at the practice level. ${ }^{19}$ Some earlier studies examining the relationship between in-hours primary care access and use of out-of-hours GP services in England were small and looked at limited number of access measures. ${ }^{20} 21$ For example, difficulty in getting an appointment with the $\mathrm{GP}^{20}$ and in getting through to the practice on the telephone $^{21}$ were associated with increased out-of-hours primary care use. However, there is no substantial evidence on the impact of access to in-hours primary care on the use of out-of-hours GP services.

Strengths of our study include the large survey sample, the ability to analyse patient-level data, the fact that findings were adjusted for sociodemographic characteristics of patients and the use of a validated questionnaire for the survey. 22

Table 3 Reduction in reported out-of-hours use that is potentially achievable by optimising access to in-hours care

\begin{tabular}{lll}
\hline & $\begin{array}{l}\text { \% of responders reporting } \\
\text { using out of hours services } \\
\text { in past } 6 \text { months }\end{array}$ & $\begin{array}{l}\text { Relative } \\
\text { reduction (\%) }\end{array}$ \\
\hline $\begin{array}{l}\text { Current use } \\
\begin{array}{l}\text { Use if access scores all } \\
\text { changed to the best } \\
\text { category }\end{array}\end{array}$ & 7.47 & - \\
\hline
\end{tabular}


A limitation of this study is the inability to evaluate the appropriateness of the out-of-hours contact. Nevertheless, it is not reasonable to assume that all episodes of out-of-hours use observed for patients who reported greater difficulties in accessing in-hours care could have been judged appropriate. Second, individual variation in ability to self-manage, past experiences of both in-hours and out-of-hours care and individual values and cultural attitudes may all influence the propensity to use out-of-hours care. ${ }^{24}$ Caution must be exercised when assuming an association may be causal when using observational data. A further limitation of our study is that there may be a potential for endogeneity in the association between in-hours access and out of-hours use, in that patients who report poor access to daytime GP services may be higher users of both in-hours and out-of-hours services. If this were to be the case, the findings do not necessarily imply that the poor access has led to increased out-of-hours use.

It is commonly believed that some patients are unable to attend for routine or urgent issues during usual surgery opening hours due to daytime commitments, particularly full-time employment. $^{25}$ This is supported by evidence that patients are willing to trade-off speed of access to care for more convenient appointments for acute and chronic problems, ${ }^{26} 27$ and that increasing the daytime capacity by offering more appointments does not necessarily lead to increased patient satisfaction. ${ }^{28}$ However, contrary to expectations, our study found that the association between out-of-hours use and convenience of opening hours was in fact stronger among those in part-time work and those not in work or education. This may mean that a more effective approach to reducing demand for out-of-hours primary care is to try to improve in-hours access as opposed to extending opening hours. For example, many practices do not offer appointments between late morning and mid-afternoon, but some patients may find such times preferable. Offering greater availability of appointments at times convenient for these groups of people may have an effect on the use of out-of-hours care.

Our study estimates the impact on out-of-hours GP use at the population level if all four in-hours access measures were improved to their best possible experience. Our estimated numbers must be treated with a fair degree of caution. First, this impact calculation does not include those who report contacting out-of-hours services for someone else. Importantly the proportion of responders who reported contacting out-of-hours services for someone else is slightly bigger than those who only contacted out-of-hours services for themselves. While it is likely that in-hours access issues may still be a predictor of contacting out-of-hours primary care for someone else, available data do not allow us to directly consider such use. Second, our estimate does not include people who have not seen their GP in the last 6 months but have nevertheless used out-of-hours primary care services; however, this patient group only accounts for a small proportion of all out-of-hours service users. Third, our model only considers the potential impact of improvements among patients who report worse access. However, implementation of interventions to effectively improve access at a given practice will also benefit those patients at that practice who have recently reported good access, leading to an underestimation of the true potential impact. The above limitations should be borne in mind. Although it should be acknowledged that achieving optimal experience of in-hours access for every patient is unrealistic, the relative reduction of $11 \%$ in out-of-hours use serves as an illustration of the need to develop interventions to improve in-hours access to primary care.
This study highlights the organisational aspect of access that can be targeted for interventions to reduce use of out-of-hours primary care in England. However, access is a multidimensional construct, ${ }^{29} 30$ and it is important to bear in mind patient characteristics that can affect a patient's healthcare seeking behaviour. $^{30}$ Research comparing patient experiences and objective measures of quality of care can provide invaluable insights into the factors that underpin patient preferences and satisfaction with the healthcare system, ${ }^{31}$ illuminating psychosocial and cognitive factors that may affect the use of in-hours GP services. More research is also required to determine whether patient-reported satisfaction with and convenience of opening hours are affected by individual circumstances such as personal responsibilities (eg, child care arrangements, caring responsibilities).

In conclusion, we found strong evidence that difficulties in accessing in-hours primary care are associated with higher use of out-of-hours primary care in England. The findings can help further motivate the development of interventions to improve patient experience of in-hour access.

Contributors GA, GL and YZ planned, analysed and wrote the article. JC, MR and FW contributed to the critical revision of the article. GL is the principal supervisor of the study.

Funding This project is independent research arising from an Academic Clinical Fellowship awarded to YZ by the East of England Multi-Professional Deanery. GL is supported by a postdoctoral fellowship by the National Institute for Health Research (PDF-2011-04-047). The analyses form part of a larger programme of research on the GP Patient Survey funded by the Department of Health.

Competing interests MR and JC act as academic advisers to Ipsos MORI for the English GP Patient Survey. Other authors have no potential conflict of interest. The views expressed in this publication are those of the authors and not necessarily those of the NHS, the National Institute for Health Research or the Department of Health.

Provenance and peer review Not commissioned; externally peer reviewed.

Open Access This is an Open Access article distributed in accordance with the Creative Commons Attribution Non Commercial (CC BY-NC 3.0) license, which permits others to distribute, remix, adapt, build upon this work non-commercially, and license their derivative works on different terms, provided the original work is properly cited and the use is non-commercial. See: http://creativecommons.org/ licenses/by-nc/3.0/

\section{REFERENCES}

1 BMA News. Call for out-of-hours investment boost. 2013. http://bma.org.uk/ news-views-analysis/news/2013/march/call-for-out-of-hours-investment-boost (accessed 30 Apr 2013).

2 Department of Health. Raising standards for patients new partnerships in out-of-hours care. London: Department of Health, 2000.

3 BMA News. Out-of-hours care failings exposed by whistleblowers. 2013. http://bma.org. uk/news-views-analysis/news/2013/march/out-of-hours-care-failings-exposed-bywhistleblowers (accessed 30 Apr 2013).

4 Freeman G, Huges J. Continuity of care and the patient experience. London: The King's Fund, 2010.

5 Spence D. Who's to blame for overcrowding in accident and emergency departments? BMJ 2013;346:f2871.

6 Winnett R. GPs blamed for crisis in out-of-hours health care. 2013. http://www. telegraph.co.uk/health/healthnews/10016521/GPs-blamed-for-crisis-in-out-of-hourshealth-care.html. (accessed 30 Apr 2013).

7 BMA News. GPs not to blame for emergency pressures. 2013. http://bma.org.uk/ news-views-analysis/news/2013/april/gps-not-to-blame-for-emergency-pressures (accessed 30 Apr 2013).

8 MORI I. Technical Annex for the GP Patient Survey: 2011-2012 Annual Report. 2012. http://www.gp-patient.co.uk/results/download/_y6q2/y6w2_AnnualTechnical. pdf (accessed 30 Apr 2013).

9 Department for Communities and Local Government. English Indices of Deprivation 2010. 2013. http://data.gov.uk/dataset/index-of-multiple-deprivation (accessed 30 Apr 2013).

10 Kontopantelis E, Roland M, Reeves D. Patient experience of access to primary care: identification of predictors in a national patient survey. BMC Fam Pract 2010;11:61. 


\section{Original article}

11 Paddison C, Elliott M, Parker R, et al. Should measures of patient experience in primary care be adjusted for case mix? Evidence from the English General Practice Patient Survey. BMJ Qual Saf 2012;21:634-40.

12 Abernethie L, Nagree Y. Increased emergency department attendance: a qualitative investigation of health seeking behaviours. Just Policy J Aust Soc Policy 2004;33:6-16.

13 Calderon-Larranaga A, Carney L, Soljak M, et al. Association of population and primary healthcare factors with hospital admission rates for chronic obstructive pulmonary disease in England: national cross-sectional study. Thorax 2011;66:191-6.

14 Carret MLV, Fassa AG, Kawachi I. Demand for emergency health service: factors associated with inappropriate use. BMC Health Serv Res 2007;7:131.

15 Baker R, Bankart M, Rashid A, et al. Characteristics of general practices associated with emergency-department attendance rates: a cross-sectional study. BMJ Qual Saf 2011;20:953-8.

16 Bankart M, Baker R, Rashid A, et al. Characteristics of general practices associated with emergency admission rates to hospital: a cross-sectional study. Emerg Med J 2011;28:558-63.

17 Lowe RA, Localio AR, Schwarz DF, et al. Association between primary care practice characteristics and emergency department use in a Medicaid managed care organization. Med Care 2005;43:792-800.

18 Christakis DA, Mell L, Koepsell TD, et al. Association of lower continuity of care with greater risk of emergency department use and hospitalization in children. Pediatrics 2001;107:524-9.

19 Cowling TE, Cecil EV, Soljak MA, et al. Access to Primary Care and Visits to Emergency Departments in England: A Cross-Sectional, Population-Based Study. PLOS ONE 2013;8:e66699.

20 Campbell J. Out of hours workload. Br J Gen Pract 1990;40:215.
21 McCarthy M, Bollam M. Telephone advice for out of hours calls in general practice. Br J Gen Pract 1990;40:19.

22 Campbell J, Smith P, Nissen S, et al. The GP Patient Survey for use in primary care in the National Health Service in the UK-development and psychometric characteristics. BMC Fam Pract 2009; 10:57.

23 Campbell J, Carter M, Davey A, et al. Accessing primary care: a simulated patient study. Br J Gen Pract 2013;63:e171-6.

24 Langer $S$, Chew-Graham C, Hunter $C$, et al. Why do patients with long-term conditions use unscheduled care? A qualitative literature review. Health Soc Care Community 2012 (Epub 25 Sep 2012).

25 Department of Health. World class commissioning for GP services: improving GP access and responsiveness. Department of Health, 2009.

26 Gerard K, Salisbury C, Street D, et al. Is fast access to general practice all that should matter? A discrete choice experiment of patients' preferences. J Health Serv Res Policy 2008;13(Suppl 2):3-10.

27 Rubin G, Bate A, George A, et al. Preferences for access to the GP: a discrete choice experiment. Br J Gen Pract 2006;56:743.

28 Sampson F, Pickin M, O'Cathain A, et al. Impact of same-day appointments on patient satisfaction with general practice appointment systems. Br J Gen Pract 2008;58:641.

29 Penchansky R, Thomas JW. The concept of access: definition and relationship to consumer satisfaction. Med Care 1981;19:127-40.

30 Aday LA, Andersen R. A framework for the study of access to medical care. Health Serv Res 1974;9:208.

31 CCHSR. Improving patient experience in NHS Primary Care. Cambridge Centre for Health Services Research, 2013. http://www.cchsr.iph.cam.ac.uk/research/ developing-methods/ (accessed 30 Apr 2013). 